\title{
The Relationship between Gender and Student Engagement, Instructional Strategies, and Classroom Management of Iranian EFL Teachers
}

\author{
Reza Nejati \\ English Language Department, Shahid Rajaee Teacher Training University, Tehran, I. R. Iran \\ Mohammad Taghi Hassani \\ English Language Department, Imam Hossein University, Tehran, I. R. Iran \\ Hessam Aldin Sahrapour \\ English Language Department, Islamic Azad University, Takestan, I. R. Iran
}

\begin{abstract}
Teachers' self-efficacy is of critical significance for both female and male teachers, and it can affect their job life. In spite of the fact that some scholars have investigated self-efficacy, there are no studies regarding teachers' gender and their subscales of self-efficacy (i.e. student engagement, instructional strategies, and classroom management). Therefore, this study aimed at investigating the relationship between gender and subscales of self-efficacy of Iranian EFL teachers. So, 34 EFL teachers who were teaching in private English language institutes in Karaj were asked to complete Teachers' Sense of Efficacy Scale (TSES) questionnaire. After analyzing the data, it was revealed that males and females did not differ as far as classroom management was considered. However, they differed in terms of student engagement and instructional strategies; male teachers were better at student engagement, while female teachers were better at instructional strategies.
\end{abstract}

Index Terms - gender, subscales of self-efficacy, EFL teachers

\section{INTRODUCTION}

One reason that causes the progress of an educational system is employing qualified teachers. These teachers possess some characteristics and having high self-efficacy is one of them (Caprara, Barbaranelli, Steca, \& Malone, 2006). Therefore, teachers with high self-efficacy should be employed to promote education.

Self-efficacy is defined as "people's beliefs about their capabilities to produce designated levels of performance that exercise influence over events that affect their lives" (Bandura, 1994, p. 2).

Although some studies have been conducted to explore the relationship between teachers' gender and their selfefficacy (which the findings are controversial), no study was reviewed by the researchers to examine the relationship between teachers' gender and their subscales of self-efficacy (student engagement, instructional strategies, and classroom management). Hence, it remains unclear that in which subscales of self-efficacy female teachers are stronger, and in which ones male teachers are better. So, unlike most studies which consider implications of teachers' gender on their self-efficacy as a whole, the present study aims at exploring the relationship between gender and subscales of selfefficacy of EFL teachers.

Besides, as it was mentioned above, existing articles regarding the relationship between teachers' gender and their self-efficacy are controversial: Some of them assert that there is no relationship between teachers' gender and their selfefficacy, and some of them believe that there is a relationship: Female teachers have stronger self-efficacy than males. Hence, shortage of a definite answer adds to the importance of the present research.

This study attempts to answer the following question:

Is there a statistically significant relationship between gender and subscales of self-efficacy of Iranian EFL teachers?

\section{LITERATURE REVIEW}

\section{A. Teachers' Self-efficacy}

Bandura (1999) explained that self-efficacy operates "by influencing how threats are cognitively processed, by supporting coping actions that alter the threats, by exercising control over perturbing thought patterns and by alleviating aversive affective states" (p. 50).

Teacher self-efficacy is defined as "teacher's belief in his or her capability to organize and execute courses of action required to successfully accomplish a specific teaching task in a particular context" (Tschannen-Moran, Woolfolk Hoy, \& Hoy, 1998, p. 22). 
Chacon (2005) believed that in addition to beliefs and personal knowledge, other factors such as "impact exerted by culture and society on the teachers' expectations, roles, and social relations" (p. 258) are involved in formation of teachers' self-efficacy.

Friedman and Kass (2002) proposed a novel model of teachers' self-efficacy called Classroom and School Context (CSC). This model is composed of two dimensions of teachers' function, namely classroom and school. The first dimension is related to teachers functioning in classroom, working with students and the second dimension is related to teachers functioning outside classroom, at school, interacting with personnel, parents, principal and colleagues. As Vaezi and Fallah (2011) put it, in the second dimension, “.... teacher functions as a member of an organization [emphasis added]" (p. 1170). The considerable point of this model is expression of a dimension which is overlooked in many studies and that is organizational efficacy. This organizational efficacy, according to Cherniss (1993), influenced teachers.

\section{B. Effects of Teachers' Self-efficacy}

Teachers' performance affects their self-efficacy and self-efficacy influences teachers' performance too. If a teacher has a successful experience of working with a variety of students, this will increase their confidence, which in turn will enhance their self-efficacy, and if s/he is not successful in their experience with students, their judgment will influence their confidence and self-efficacy, which in turn, will affect the time s/he will persist in teaching (Yost, 2006). Or if a teacher considers themselves unsuccessful in dealing with a particular group of learners, s/he will not spend much energy on teaching and will stop attempting with the appearance of the first obstacle, in spite of the fact that s/he may have the required knowledge and technique to solve the problem (Tschannen-Moran \& Woolfolk Hoy, 2007). So, it can be said that "self-efficacy beliefs can therefore become self-fulfilling prophesies, validating beliefs either of capability or of incapacity" (Tschannen-Moran \& Woolfolk Hoy, 2007, p. 3).

Teachers with high levels of self-efficacy are more satisfied with their job (Caprara et al., 2006; Tschannen-Moran \& Hoy, 2002), expect a lot from themselves, stand firm when they face barriers (Ross \& Bruce, 2007), and have more endurance and flexibility (Somech \& Zahavy, 2000).

Furthermore, teachers with higher levels of self-efficacy are more confident in their teaching abilities, have more positive attitudes towards teaching, and are "active and assured in their responses to students" (Tschannen-Moran et al., 1998, p. 9). In addition, Efficacious teachers "persist longer, provide a greater academic focus in the classroom, and exhibit different types of feedback" (Tschannen-Moran et al., 1998, p. 9).

\section{METHODOLOGY}

\section{A. Participants}

Participants of this study were composed of 34 EFL teachers. Out of these 34 teachers, 22 were females and 12 were males. They were between 24 to 35 years old. These teachers were teaching in private English language institutes in Karaj.

\section{B. Instrument}

Teachers' Sense of Efficacy Scale (TSES) created by Tschannen-Moran and Woolfolk Hoy (2001) was utilized in this study. Klassen et al. (2009) maintained that TSES is reliable, and it “... showed convincing evidence of reliability and measurement invariance across the five countries" (p. 67).

Tschannen-Moran and Woolfolk Hoy (2001) investigated the validity of Ohio State Teacher Efficacy Scale (OSTES) (another name for TSES) and asserted that "the OSTES could be considered reasonably valid and reliable .... it is of reasonable length and should prove to be a useful tool for researchers interested in exploring the construct of teacher efficacy" (p. 801).

There were 24 items and three subscales in TSES. These subscales were efficacy in student engagement, efficacy in instructional strategies, and efficacy in classroom management. Eight items were related to each subscale. Items 1, 2, 4, $6,9,12,14,22$ were concerned with student engagement, items $7,10,11,17,18,20,23,24$ were pertained to instructional strategies, and items $3,5,8,13,15,16,19,21$ dealt with classroom management. These 24 items were offered on a 9-point Likert scale, ranging from: 1- nothing, to 9- a great deal (Tschannen-Moran \& Woolfolk Hoy, 2001). The reliabilities of the subscales of self-efficacy for the present study follow: 0.81 for student engagement, 0.84 for instructional strategies, and 0.71 for classroom management.

\section{Procedure}

EFL teachers received TSES questionnaire, and they were asked to answer it.

\section{Data Analysis}

A Multivariate analysis of variance (MANOVA) was run to answer the research question.

\section{RESULTS AND DISCUSSION}

The research question can be converted into the following null hypothesis: 
Hypothesis $_{0}$ : There is no statistically significant difference between male and female EFL teachers in terms of their subscales of self-efficacy.

In order to answer the research question, multivariate analysis of covariance (MANOVA) was run. Before reporting the MANOVA results, first, equality of variance is checked. As it can be seen in the following table (Table I), none of the variables recorded significant values; therefore, the researchers can assume equal variances.

TABLE I

LEVENE'S TEST OF EQUALITY OF ERROR VARIANCESA FOR GENDER AND SELF-EFFICACY SUBSCALES
\begin{tabular}{|l|l|l|l|l|}
\hline & $\mathrm{F}$ & $\mathrm{df} 1$ & $\mathrm{df} 2$ & Sig. \\
\hline Student engagement & .423 & 1 & 195 & .516 \\
Instructional strategies & .470 & 1 & 195 & .494 \\
Class management & .004 & 1 & 195 & .952 \\
\hline
\end{tabular}

Tests the null hypothesis that the error variance of the dependent variable is equal across groups.

a. Design: Intercept + gender

Second, multivariate tests are checked. This set of multivariate tests of significance indicates whether there are statistically significant differences among the groups (gender in the present study) on a linear combinations of the dependent variables, namely student engagement, instructional strategies, and classroom management or not. The multivariate tests of significance produced are Wilks' Lambda, Pillai's trace, Hotelling's Trace and Roy's Largest Root. All the values of these tests for the independent variable, namely gender, are 29.642, with a significance value of .00. This is less than the cut-off .05; therefore, there is statistically significant difference between male and female teachers in terms of student engagement, instructional strategies, and classroom management.

TABLE II

Multivariate TESTSB FOR GENDER AND SELF-EFFICACY SuBSCALES

\begin{tabular}{|ll|l|l|l|l|l|l|}
\hline Effect & Value & F & Hypothesis df & Error df & Sig. & Partial Eta Squared \\
\hline Intercept & Pillai's Trace & .992 & $7577.007^{\mathrm{a}}$ & 3.000 & 193.000 & .000 & .992 \\
& Wilks' Lambda & .008 & $7577.007^{\mathrm{a}}$ & 3.000 & 193.000 & .000 & .992 \\
& Hotelling's Trace & 117.777 & $7577.007^{\mathrm{a}}$ & 3.000 & 193.000 & .000 & .992 \\
& Roy's Largest Root & 117.777 & $7577.007^{\mathrm{a}}$ & 3.000 & 193.000 & .000 & .992 \\
\hline \multirow{2}{*}{ Gender } & Pillai's Trace & .315 & $29.642^{\mathrm{a}}$ & 3.000 & 193.000 & .000 & .315 \\
& Wilks' Lambda & .685 & $29.642^{\mathrm{a}}$ & 3.000 & 193.000 & .000 & .315 \\
& Hotelling's Trace & .461 & $29.642^{\mathrm{a}}$ & 3.000 & 193.000 & .000 & .315 \\
& Roy's Largest Root & .461 & $29.642^{\mathrm{a}}$ & 3.000 & 193.000 & .000 & .315 \\
\hline
\end{tabular}

a. Exact statistic

b. Design: intercept + gender

Third, the Tests of Between-Subjects Effects were examined. Because three separate analyses are at work here, researchers are advised to set a higher alpha level to reduce the chance of Type I error, i.e. finding a significant result when there is not really one (cf. Pallant, 2007). Hence, the alpha of .05 is divided by 3 , coming up with a new alpha level of .017. The present researchers, then, consider the results significant only if the probability value is less than .017 . As it is displayed in the following table (Table III), male and female teachers do not differ as far as classroom management is considered. However, they differ in terms of student engagement, and instructional strategies they employ. Based on the 'partial eta squared' index provided in the table of Tests of Between-Subjects Effects (Table III), .056 of the variance is accounted for by student engagement and instructional strategies factors respectively. 
TABLE III

TESTS OF BETWEEN-SUBJECTS EFFECTS FOR GENDER AND SELF-EFFICACY SUBSCALES

\begin{tabular}{|c|c|c|c|c|c|c|c|c|}
\hline Source & $\begin{array}{l}\text { Dependent } \\
\text { Variable }\end{array}$ & $\begin{array}{l}\text { Type III Sum } \\
\text { of Squares }\end{array}$ & df & $\begin{array}{l}\text { Mean } \\
\text { Square }\end{array}$ & $F$ & Sig. & $\begin{array}{l}\text { Partial Eta } \\
\text { Squared }\end{array}$ & $\begin{array}{l}\text { Noncent. } \\
\text { Parameter }\end{array}$ \\
\hline $\begin{array}{l}\text { Corrected } \\
\text { Model }\end{array}$ & $\begin{array}{l}\text { Student eng } \\
\text { Instructional str } \\
\text { Class manage }\end{array}$ & $\begin{array}{l}362.437^{\mathrm{a}} \\
383.498^{\mathrm{c}} \\
43.757^{\mathrm{d}} \\
\end{array}$ & $\begin{array}{l}1 \\
1 \\
1\end{array}$ & $\begin{array}{l}362.437 \\
383.498 \\
43.757 \\
\end{array}$ & $\begin{array}{l}11.497 \\
11.575 \\
1.068 \\
\end{array}$ & $\begin{array}{l}.001 \\
.001 \\
.303 \\
\end{array}$ & $\begin{array}{l}.056 \\
.056 \\
.005 \\
\end{array}$ & $\begin{array}{l}11.497 \\
11.575 \\
1.068 \\
\end{array}$ \\
\hline Intercept & $\begin{array}{l}\text { Student eng } \\
\text { Instructional str } \\
\text { Class manage }\end{array}$ & $\begin{array}{l}595181.218 \\
661868.168 \\
699097.158 \\
\end{array}$ & $\mid \begin{array}{l}1 \\
1 \\
1 \\
1\end{array}$ & $\begin{array}{l}595181.218 \\
661868.168 \\
699097.158 \\
\end{array}$ & $\begin{array}{l}18880.077 \\
19977.378 \\
17067.308 \\
\end{array}$ & $\begin{array}{l}.000 \\
.000 \\
.000\end{array}$ & $\begin{array}{r}.990 \\
.990 \\
.989 \\
\end{array}$ & $\begin{array}{l}18880.077 \\
19977.378 \\
17067.308 \\
\end{array}$ \\
\hline Gender & $\begin{array}{l}\text { Student eng } \\
\text { Instructional str } \\
\text { Class manage }\end{array}$ & $\begin{array}{l}362.437 \\
383.498 \\
43.757 \\
\end{array}$ & $\begin{array}{l}1 \\
1 \\
1\end{array}$ & $\begin{array}{l}362.437 \\
383.498 \\
43.757 \\
\end{array}$ & $\begin{array}{l}11.497 \\
11.575 \\
1.068 \\
\end{array}$ & $\begin{array}{l}.001 \\
.001 \\
.303 \\
\end{array}$ & $\begin{array}{l}.056 \\
.056 \\
.005 \\
\end{array}$ & $\begin{array}{l}11.497 \\
11.575 \\
1.068 \\
\end{array}$ \\
\hline Error & $\begin{array}{l}\text { Student eng } \\
\text { Instructional str } \\
\text { Class manage }\end{array}$ & $\begin{array}{l}6147.239 \\
6460.522 \\
7987.431 \\
\end{array}$ & $\begin{array}{l}195 \\
195 \\
195\end{array}$ & $\begin{array}{l}31.524 \\
33.131 \\
40.961\end{array}$ & & & & \\
\hline Total & $\begin{array}{l}\text { Student eng } \\
\text { Instructional str } \\
\text { Class manage }\end{array}$ & $\begin{array}{l}668290.000 \\
767588.000 \\
802829.000 \\
\end{array}$ & $\begin{array}{l}197 \\
197 \\
197\end{array}$ & & & & & \\
\hline $\begin{array}{l}\text { Corrected } \\
\text { Total }\end{array}$ & $\begin{array}{l}\text { Student eng } \\
\text { Instructional str } \\
\text { Class manage }\end{array}$ & $\begin{array}{l}6509.675 \\
6844.020 \\
8031.188\end{array}$ & $\begin{array}{l}196 \\
196 \\
196\end{array}$ & & & & & \\
\hline & & $\begin{array}{l}\text { a. } \mathrm{F} \\
\text { c. } \mathrm{F} \\
\text { d. } \mathrm{F}\end{array}$ & $\begin{array}{l}\text { duare } \\
\text { b. } \\
\text { quare } \\
\text { quare }\end{array}$ & $\begin{array}{l}.056 \text { (Adjus } \\
\text { nputed usin } \\
.056 \text { (Adjus } \\
.005 \text { (Adjus }\end{array}$ & $\begin{array}{l}\text { Squared }=. \\
\text { a }=.05 \\
\text { Squared }=. \\
\text { Squared }=\end{array}$ & & & \\
\hline
\end{tabular}

As it was mentioned above, male and female teachers differ in terms of student engagement, and instructional strategies they employ. The question is where the difference lies. In order to answer this question, the researchers examined the table of pairwise comparisons (Table IV). According to the Table IV, male teachers are better at student engagement, however female teachers are better at instructional strategies. So, the null hypothesis is rejected.

TABLE IV

PAIRWISE COMPARISONS FOR GENDER AND SELF-EFFICACY SUBSCALES

\begin{tabular}{|c|c|c|c|c|c|c|c|}
\hline \multirow[b]{2}{*}{ Dependent Variable } & \multirow[b]{2}{*}{ (I) Gender } & \multirow[b]{2}{*}{ (J) Gender } & \multirow[b]{2}{*}{ Mean Difference (I-J) } & \multirow[b]{2}{*}{ Std. Error } & \multirow[b]{2}{*}{ Sig. ${ }^{\text {a }}$} & \multicolumn{2}{|c|}{$95 \%$ Confidence Interval for Difference ${ }^{a}$} \\
\hline & & & & & & Lower Bound & Upper Bound \\
\hline \multirow[t]{2}{*}{ Student eng } & Female & Male & $-2.885^{*}$ & .851 & .001 & -4.563 & -1.207 \\
\hline & Male & Female & $2.885^{*}$ & .851 & .001 & 1.207 & 4.563 \\
\hline \multirow[t]{2}{*}{ Instructional str } & Female & Male & $2.967^{*}$ & .872 & .001 & 1.247 & 4.687 \\
\hline & Male & Female & $-2.967^{*}$ & .872 & .001 & -4.687 & -1.247 \\
\hline \multirow[t]{2}{*}{ Class manage } & Female & Male & 1.002 & .970 & .303 & -.910 & 2.915 \\
\hline & Male & Female & -1.002 & .970 & .303 & -2.915 & .910 \\
\hline
\end{tabular}

Based on estimated marginal means

*. The mean difference is significant at the .05 level.

a. Adjustment for multiple comparisons: Bonferroni.

\section{CONCLUSION}

The present study investigated the relationship between gender and subscales of self-efficacy of Iranian EFL teachers. Therefore, difference between male and female teachers in terms of subscales of self-efficacy (student engagement, instruction strategies, and classroom management) was explored and the outcomes showed that males and females do not differ as far as classroom management is considered. However, they differed in terms of student engagement and instructional strategies they employ; male teachers were better at student engagement, while female teachers were better at instructional strategies.

Andersen (2011), Cheung (2006), Coladarci (1992), Coladarci and Breton (1997), Naseri Karimvand (2011), Raudenbush, Rowan, and Cheong (1992), and Ross (1994) found that female teachers have higher self-efficacy than male teachers. Anderson, Greene, and Loewen (1988), Evans and Tribble (1986), Gavora (2011), and Greenwood, Olejnik, and Parkay (1990) found that female teachers have higher personal teaching efficacy than male teachers.

Garvis (2009), Gencer and Cakiroglu (2007), Ghaith and Shaaban (1999), Hashemi and Ghanizadeh (2011), Hoy and Woolfolk (1993), Lee, Dedrick, and Smith (1991), Pajares (2002), Taimalu and Oim (2005), Tschannen-Moran and Hoy (2002), Tschannen-Moran and Hoy (2007), and Wilson and Tan (2004) in their studies demonstrated that there is no relationship between gender and self-efficacy, i.e. males and females do not differ in terms of self-efficacy.

On the one hand, it can be claimed that women are usually more attentive than men. They pay attention to details more than men do, and women are more careful in doing their job. Women are usually more organized than men, and try to do their job as carefully as they can. These are true in the case of teaching as well: Because female teachers are 
more attentive, accurate and organized than men, they usually attempt to have the best instruction. They are usually sensitive to teach as effectively as they can and not to skip anything because they pay attention to details.

On the other hand, men usually do not wish to be the only speaker; even they prefer not to talk too much. Maybe it is due to this characteristic that male teachers prefer to engage learners more in teaching and allow them to have role in classroom and in their (learners) learning.

Furthermore, in traditional educational system, when teachers did not have the role of facilitator, a good teacher was a person who did everything needed and left very few things for learners to do. If s/he spoke little, or left a lot of tasks for learners to do, people possibly assumed that $\mathrm{s} / \mathrm{he}$ was not a good teacher and $\mathrm{s} / \mathrm{he}$ did not teach. Nowadays, this belief still exists among some learners and their parents. Maybe women because of their caution and fear of dismissal or demotion, follow the traditional educational principles, and do not provide the learners with the chance to be engaged in learning. However, men do the contrary: They engage learners in learning, and allow them to express themselves because men are more dauntless than women.

The findings of the present study may have the following implications for teacher trainers and teachers. Teacher trainers should run special courses for male and female teachers. Since the results of this piece of research indicated that male teachers were not strong in instructional strategies, in courses for male teachers, teacher trainers should try to focus on instructional strategies. They need to work on variant types and models of instructional strategies, and help male teachers to improve their abilities in the realm of instructional strategies. While running courses for female teachers, teacher trainers are required to help female teachers to develop their skills in engaging students. The findings of the present study showed that female teachers are not strong in engaging students, so teacher trainers should explain the necessity and methods of students' engagement to female teachers.

Male and female teachers themselves need to focus on developing the self-efficacy subscales in which they are not strong. Hence, Male teachers should concentrate on enhancing their instructional strategies, and female teachers should try to develop their efficacy in student engagement.

\section{APPENDIX. OSTES QUESTIONNAIRE}




\begin{tabular}{|c|c|c|c|c|c|c|c|c|c|c|}
\hline & Teacher Beliefs & & HoI & w r & lucl & cal & n yc & ou d & do? & \\
\hline & $\begin{array}{l}\text { Directions: This questionnaire is designed to help us gain a better understanding of the } \\
\text { kinds of things that create difficulties for teachers in their school activities. Please indicate } \\
\text { your opinion about each of the statements below. Your answers are confidential. }\end{array}$ & 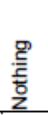 & & 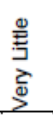 & & 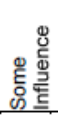 & & 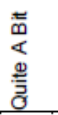 & & 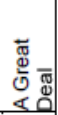 \\
\hline 1. & How much can you do to get through to the most difficult students? & (1) & $(2)$ & (3) & (4) & $(5)$ & $(6)$ & (7) & $(8)$ & (9) \\
\hline 2. & How much can you do to help your students think critically? & (1) & $(2)$ & (3) & (4) & $(5)$ & $(6)$ & (7) & $(8)$ & (9) \\
\hline 3. & How much can you do to control disruptive behavior in the classroom? & (1) & $(2)$ & (3) & (4) & $(5)$ & $(6)$ & (7) & $(8)$ & (9) \\
\hline 4. & $\begin{array}{l}\text { How much can you do to motivate students who show low interest in school } \\
\text { work? }\end{array}$ & (1) & $(2)$ & (3) & (4) & $(5)$ & $(6)$ & (7) & $(8)$ & (9) \\
\hline 5. & To what extent can you make your expectations clear about student behavior? & (1) & $(2)$ & (3) & (4) & (5) & $(6)$ & $(7)$ & $(8)$ & (9) \\
\hline 6. & How much can you do to get students to believe they can do well in school work? & (1) & $(2)$ & (3) & (4) & (5) & $(6)$ & (7) & $(8)$ & (9) \\
\hline 7. & How well can you respond to difficult questions from your students? & (1) & $(2)$ & (3) & (4) & $(5)$ & $(6)$ & (7) & $(8)$ & (9) \\
\hline 8. & How well can you establish routines to keep activities running smoothly? & (1) & $(2)$ & (3) & (4) & (5) & $(6)$ & (7) & $(8)$ & (9) \\
\hline 9. & How much can you do to help your students value learning? & (1) & $(2)$ & (3) & (4) & (5) & $(6)$ & (7) & $(8)$ & (9) \\
\hline 10. & How much can you gauge student comprehension of what you have taught? & (1) & $(2)$ & (3) & (4) & (5) & $(6)$ & (7) & $(8)$ & (9) \\
\hline 11. & To what extent can you craft good questions for your students? & (1) & $(2)$ & (3) & (4) & $(5)$ & $(6)$ & (7) & $(8)$ & (9) \\
\hline 12. & How much can you do to foster student creativity? & (1) & $(2)$ & (3) & (4) & (5) & $(6)$ & (7) & $(8)$ & (9) \\
\hline 13. & How much can you do to get children to follow classroom rules? & (1) & $(2)$ & (3) & (4) & (5) & $(6)$ & (7) & $(8)$ & (9) \\
\hline 14. & How much can you do to improve the understanding of a student who is failing? & (1) & $(2)$ & (3) & (4) & (5) & $(6)$ & (7) & $(8)$ & (9) \\
\hline 15. & How much can you do to calm a student who is disruptive or noisy? & (1) & $(2)$ & (3) & (4) & (5) & $(6)$ & (7) & $(8)$ & (9) \\
\hline 16. & $\begin{array}{l}\text { How well can you establish a classroom management system with each group of } \\
\text { students? }\end{array}$ & (1) & $(2)$ & (3) & (4) & $(5)$ & $(6)$ & (7) & $(8)$ & (9) \\
\hline 17. & $\begin{array}{l}\text { How much can you do to adjust your lessons to the proper level for individual } \\
\text { students? }\end{array}$ & (1) & $(2)$ & (3) & (4) & $(5)$ & $(6)$ & (7) & $(8)$ & (9) \\
\hline 18. & How much can you use a variety of assessment strategies? & (1) & $(2)$ & (3) & (4) & (5) & $(6)$ & (7) & $(8)$ & (9) \\
\hline 19. & How well can you keep a few problem students form ruining an entire lesson? & (1) & $(2)$ & (3) & (4) & $(5)$ & $(6)$ & (7) & $(8)$ & (9) \\
\hline 20. & $\begin{array}{l}\text { To what extent can you provide an alternative explanation or example when } \\
\text { students are confused? }\end{array}$ & (1) & $(2)$ & (3) & (4) & $(5)$ & (6) & (7) & $(8)$ & (9) \\
\hline 21. & How well can you respond to defiant students? & (1) & $(2)$ & (3) & (4) & $(5)$ & (6) & (7) & $(8)$ & (9) \\
\hline 22. & How much can you assist families in helping their children do well in school? & (1) & $(2)$ & (3) & (4) & (5) & (6) & (7) & $(8)$ & (9) \\
\hline 23. & How well can you implement alternative strategies in your classroom? & (1) & $(2)$ & (3) & (4) & (5) & $(6)$ & (7) & $(8)$ & (9) \\
\hline 24. & How well can you provide appropriate challenges for very capable students? & (1) & (2) & (3) & (4) & (5) & (6) & (7) & (8) & (9) \\
\hline
\end{tabular}

\section{ACKNOWLEDGMENT}

I would like to thank my parents who supported me, and Dr. Reza Nejati, Dr. Mohammad Taghi Hassani, and Dr. Ramin Rahmani for guiding me. Heads, teachers and supervisors of the following foreign language institutes willingly cooperated with me in doing this research, and I am grateful to all of them: Bagher-al-oloum (peace be upon him), Ghalam-e-Novin, Honar-e-Farzanegan-e-Alborz, Khazaeli, Kish Way, Mani, Mehr, Nashr-e-Sokhan, Nasir, Safir-eMehr.

\section{REFERENCES}

[1] Andersen, L. B. (2011). Teacher diversity: Do male and female teachers have different self-efficacy and job satisfaction? Paper prepared for the 33rd EGPA conference in Bucharest, 1-17.

[2] Anderson, R., Greene, M., \& Loewen, P. (1988). Relationships among teachers' and students' thinking skills, sense of efficacy, and student achievement. Alberta Journal of Educational Research, 34(2), 148-165.

[3] Bandura, A. (1994). Self-efficacy. In V. S. Ramachaudran (Eds.), Encyclopedia of human behavior (pp. 71-81). New York: Academic Press (Reprinted in H. Friedman [Eds.], Encyclopedia of mental health. San Diego: Academic Press).

[4] Bandura, A. (1999). Social cognitive theory of personality. In L. Pervn, \& O. John (Eds.), Handbook of personality theory and research (pp. 154-196). New York: The Guilford Press. 
[5] Caprara, G., Barbaranelli, C., Steca, p., \& Malone, P. (2006). Teachers' self-efficacy beliefs as determinants of job satisfaction and students' academic achievement: A study at the school level. Journal of School Psychology, 44, 473-490.

[6] Chacon, C. T. (2005). Teachers' perceived efficacy among English as a foreign language teachers in middle schools in Venezuela. Teaching and Teacher Education, 21, 257-272.

[7] Cherniss, C. (1993). Role of professional self-efficacy in the etiology and amelioration of burnout. In W.B. Shaufeli, C. Maslach, \& T. Marek (Eds.), Professional burnout: Recent developments in theory and research. Washington, D.C.: Taylor \& Francis.

[8] Cheung, Hoi-Yan. (2006). The measurement of teacher efficacy: Hong Kong primary in-service teachers. Journal of Education for Teaching, 32(4), 435-451.

[9] Coladarci, T. (1992).Teachers' sense of efficacy and commitment to teaching. Journal of Experimental Education, 60(4), 323337.

[10] Coladarci, T., \& Breton, W. A. (1997).Teacher efficacy, supervision, and the special education resource-room teacher. Journal of Educational Research, 90(4), 230-239.

[11] Evans, E. D., \& Tribble, M. (1986).Perceived teaching problems, self-efficacy, and commitment to teaching among preservice teachers. Journal of Educational Research, 80(2), 81-85.

[12] Friedman, I. A., \& Kass, E. (2002). Teacher self-efficacy: A classroom-organization conceptualization. Teaching and Teacher Education, 18, 675-686.

[13] Garvis, S. (2009). Establishing the theoretical construct of pre-service teacher self-efficacy for arts education. Australian Journal of Music Education, 1, 29-37.

[14] Gavora, P. (2011). Measuring the self-efficacy of in-service teachers in Slovakia. Orbis Scholae, 5(2), 79-94.

[15] Gencer, A. S., \& Cakiroglu, J. (2007).Turkish preservice science teachers' efficacy beliefs regarding science teaching and their beliefs about classroom management. Teaching and Teacher Education, 23, 664-675.

[16] Ghaith, G., \& Shaaban, K. (1999). The relationship between perceptions of teaching concerns, teacher efficacy, and selected teacher characteristics. Teaching and Teacher Education, 15, 487-496.

[17] Greenwood, G., Olejnik, S., \& Parkay, F. (1990). Relationships between four teacher efficacy belief patterns and selected teacher characteristics. Journal of Research and Development in Education, 2 (2), 102-107.

[18] Hashemi, M. R., \& Ghanizadeh, A. (2011). Emotional intelligence and self-efficacy: A case of Iranian EFL university students. International Journal of Linguistics, 3(1), 1-16.

[19] Hoy, W. K., \& Woolfolk, A. E. (1993). Teachers' sense of efficacy and the organizational health of schools. The Elementary School Journal, 93 (4), 355-372.

[20] Klassen, R. B., Bong, M., Usher, E. L., Chong, W. H., Huan, V. S., Wong., I. Y. F., \& Georgiou, T. (2009). Exploring the validity of teachers' self-efficacy scale in five countries. Contemporary Educational Psychology, 34, 67-76.

[21] Lee, V. E., Dedrick, R. F., \& Smith, J. B. (1991). The effect of the social organization of schools on teachers' efficacy and satisfaction. Sociology of Education, 64(3), 190-208.

[22] Naseri Karimvand, P. (2011). The nexus between Iranian EFL teachers' self-efficacy, teaching experience and gender. Canadian Center of Science and Education, 4(3), 171-183.

[23] Pajares, F. (2002).Overview of social cognitive theory and self-efficacy. Retrieved September 03, 2013, from http://www.uky.edu/ eushe2/Pajares/eff.html

[24] Pallant, J. (2007). SPSS survival manual: A step by step guide to data analysis using SPSS version 15 (3 ${ }^{\text {rd }}$ ed.). Berkshire: Open University Press.

[25] Raudenbush, S. W., Rowan, B., \& Cheong, Y. F. (1992).Contextual effects on the self perceived efficacy of high school teachers. Sociology of Education, 65(2), 150-167.

[26] Ross, J. A. (1994). Beliefs that makes a difference: The origin and impact of teacher efficacy. A paper presented at the annual meeting of the Canadian association for curriculum studies Calgary.

[27] Ross, J. A., \& Bruce, C. (2007).Professional development effects on teacher efficacy; results of randomized field trial. The Journal of Educational Research. 101(1), 50-66.

[28] Somech, A., \& Zahavy, A. D. (2000). Understanding extra-role behavior in schools: The relationships between job satisfaction, sense of efficacy, and teachers' extra-role behavior. Teaching and Teacher Education, 16, 649- 659.

[29] Taimalu, M., \& Oim, O. (2005). Estonian teachers' beliefs on teacher efficacy and influencing factors. Trames, 9(2), 177-191.

[30] Tschannen-Moran, M., Woolfolk Hoy, A., \& Hoy, W. K. (1998). Teacher efficacy: Its meaning and measure. Review of Educational Research, 68, 202-248.

[31] Tschannen-Moran, M., \& Woolfolk Hoy, A. (2001). Teacher efficacy: Capturing an elusive construct. Teaching and Teacher Education, 17, 783-805.

[32] Tschannen-Moran, M., \& Woolfolk Hoy, A. (2002).The influence of resources and support on teachers' efficacy beliefs. Paper presented at the annual meeting of the American Educational Research Association. New Orleans, LA.

[33] Tschannen-Moran, M., \& Woolfolk Hoy, A. (2007).The differential antecedents of self-efficacy beliefs of novice and experienced teachers. Teaching and Teacher Education, 23, 944-956.

[34] Vaezi, S., \& Fallah, N. (2011). The relationship between self-efficacy and stress among Iranian EFL teachers. Journal of Language Teaching and Research, 2(5), 1168-1674.

[35] Wilson, P., \& Tan, G.I. (2004).Singapore teachers' personal and general efficacy for teaching primary social studies. International Research in Geographical and Environmental Education, 13(3), 209-222.

[36] Yost, D. S. (2006).Reflection and self-efficacy: Enhancing the retention of qualified teachers from a teacher education perspective. Teacher Education Quarterly, 33(4), 59-76. 

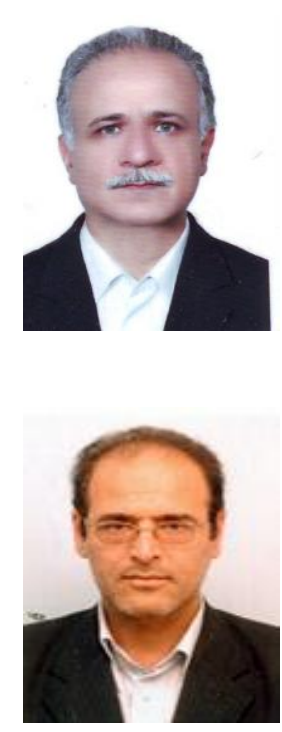

Mohammad Taghi Hassani is a Ph.D. holder of teaching English as a foreign language from Allameh Tabatabaee University, Iran. Currently, he is an assistant professor in Imam Hossein University, Tehran and Islamic Azad University, Takestan Branch, Iran.

His research interests are EFL writing, psycholinguistics, phonetics, contrastive analysis, English for Specific Purposes, and language teaching methodology.

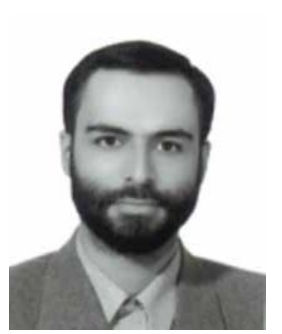

Hessam Aldin Sahrapour holds an MA degree in Teaching English as a Foreign Language (TEFL) from Islamic Azad University of Takestan, Iran. He received his BA in English translation in 2008 and his MA in 2013. He has been teaching English for over three years. His major fields of interest include teacher education, language teaching methodology, language acquisition, language testing, and discourse analysis. 